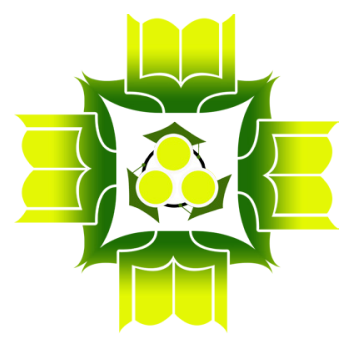

\title{
STEM EDUCATION RESEARCH IN INDONESIAN ELEMENTARY SCHOOLS: A SYSTEMATIC REVIEW OF PROJECT-BASED LEARNING
}

\author{
Muhamad Imaduddin \\ Institut Agama Islam Negeri Kudus \\ imad@iainkudus.ac.id \\ Sholikhati \\ Institut Agama Islam Negeri Kudus \\ sholikhah168@gmail.com \\ Moh. In'ami \\ Institut Agama Islam Negeri Kudus \\ mohinami@iainkudus.ac.id
}

\begin{abstract}
STEM Education, in various countries including Indonesia, is growing with a variety of classroom learning projects in elementary schools. This study aims to describe the development of basic education STEM research in Indonesia and the various types of learning projects developed based on the curriculum using systematic review. The technique of systematic review is qualitative (meta-synthesis). The primary sources in this study are various works of literature on STEM basic education contained in scientific journals indexed on the SINTA indexing page ranked 1-6 with the years of publication in 20172020. The data is analyzed using the Preferred Reporting Items for Systematic Review and Meta-Analysis (PRISMA) method. The implementation has several steps consisting of (1) identifying research questions, (2) developing research protocols, (3) determining the location of the search area database, (4) selecting relevant research results, (5) selection criteria, (6) data extraction, (7) synthesizing results using meta-synthesis, and (8) presenting results. The most distribution of articles on STEM education themes was found in journals with the scope of educational studies that were ranked at Sinta 3. A review of 17 articles showed that there were variations in projects that could
\end{abstract}


be analyzed further from the 7 articles. Learning projects cover recreational, environmental, and energy topics. Research on STEM learning projects tends to be carried out in upper grades in elementary schools.

Keywords: STEM Education Research, Indonesian Elementary Schools, Project-Based Learning.

\section{Abstrak}

STEM Education, di berbagai negara termasuk Indonesia, semakin berkembang dengan ragam proyek pembelajaran kelas pada sekolah dasar. Penelitian ini bertujuan untuk mendeskripsikan perkembangan penelitian STEM pendidikan dasar di Indonesia dan berbagai jenis proyek pembelajaran yang dikembangkan berdasarkan kurikulum dengan menggunakan systematic review. Teknik systematic review adalah teknik kualitatif (meta-sintesis). Sumber utama dalam penelitian ini adalah berbagai literatur tentang pendidikan dasar STEM yang terdapat pada jurnal ilmiah yang terindeks pada halaman indexing SINTA peringkat 1-6 dengan tahun terbit 2017-2020. Data dianalisis menggunakan metode Preferred Reporting Items for Systematic Review and Meta-Analysis (PRISMA). Pelaksanaannya memiliki beberapa langkah yang terdiri dari (1) mengidentifikasi pertanyaan penelitian, (2) mengembangkan protokol penelitian, (3) menentukan lokasi basis data area pencarian, (4) memilih hasil penelitian yang relevan, (5) kriteria pemilihan, (6) ekstraksi data, (7) mensintesis hasil menggunakan meta-sintesis, dan (8) menyajikan hasil. Distribusi artikel bertema pendidikan STEM terbanyak terdapat pada jurnal dengan lingkup kajian pendidikan yang berada pada peringkat Sinta 3. Review dari 17 artikel menunjukkan bahwa terdapat variasi proyek yang dapat dianalisis lebih lanjut dari 7 artikel tersebut. Proyek pembelajaran mencakup topik rekreasi, lingkungan, dan energi. Penelitian tentang proyek pembelajaran STEM cenderung dilakukan di kelas atas di sekolah dasar.

Kata Kunci: Penelitian Pendidikan STEM, Sekolah Dasar Indonesia, Pembelajaran Berbasis Proyek.

\section{INTRODUCTION}

STEM education is an integrated learning approach between science, technology, engineering, and mathematics (STEM) to develop students' creativity and problem-solving skills in everyday life (Winarni et al., 2016). Since the early 20th century, many schools in the United States have begun to focus on STEM education. In various parts of the world, there have been movements to develop 
schools that focus on STEM learning such as Australia, England, Scotland, and the United States which have published national recommendations to support the STEM movement. The K-12 curriculum for STEM has been developed in Australia, China, UK, Korea, Taiwan, and the US combining multi-disciplinary with projectbased pedagogical principles. France, Japan, and South Africa have also focused on informal STEM experiences outside of school to address this challenge (Slavit et al., 2016). The Australian state has started teaching STEM learning to citizens aged around 11-18 years on coding material that produces robots as a final project within 3 months with very supportive facilities and infrastructure (Wijokongko, 2009). The implementation of STEM learning has also been carried out in Turkey through the implementation of learning at the 3rd grade of Elementary School by teaching the unit "Let's Get to Know the Problem" (Ultay et al., 2020). The results of this study indicated that in subjects that are focused on STEM, students can solve problems by producing boat toys and raincoats from the results of their creativity. Taiwan, which has also emphasized the concept of learning by doing in 2010, has shown research related to students who can produce products from the Do It Yourself (DIY) process in the form of Cup Speakers in STEM learning (Lou et al., 2010).

Since the implementation of the 2013 curriculum in Indonesia as the national education curriculum, STEM-based learning at the elementary school level in Indonesia has begun to be implemented in recent years and has experienced a significant increase in efforts to improve the quality of education. STEM-based learning began to be introduced in public elementary schools in Jombang, East Java, Indonesia with robotic learning on broad-field materials and basic structures carried out in the 5 th and 6 th grades using an action learning system (Faridawati et al., 2020). The results showed that 66 of the 78 students had understood the material that had been taught. Ethno-STEM-based science learning in elementary schools has also been carried out in public elementary schools in West Kalimantan, Indonesia by applying a digital microscope (Priyani \& Nawawi, 2020). EthnoSTEM-based science learning assisted by a simple digital microscope can improve students' science process skills and can be an effective learning model and media in learning activities. 
STEM education at the elementary school level is the first step to foster student interest in STEM by learning the principles of STEM knowledge by linking knowledge with real issues or problems in everyday life (Sariah, 2016). STEM at the elementary school level can be applied as a solution to solving problems in children's daily lives. STEM education in elementary schools can lead students to identify problems, discuss to exchange ideas, design from selected ideas, create, and evaluate projects that have been produced (Lidinillah et al., 2019). Introducing and teaching STEM at the elementary school level is very important in fostering interest in science, technology, engineering, and mathematics to deal with various phenomena that exist in everyday life. STEM learning trains 21st-century skills, namely critical thinking, communication, collaboration, and creativity. This can be one of the efforts to create quality future generations and be able to contribute to improving human resources. One of the efforts of the Indonesian government in improving the quality of education is by initiating a policy, namely the Indonesia 4.0 policy. The Ministry of Industry has initiated the Indonesia 4.0 policy, in which there are 10 national priorities, one of which is improving the quality of human resources with the STEAM education curriculum pattern (Science, Technology, Engineering, Art, and Mathematics) (Kementerian Perindustrian Republik Indonesia, 2018). With the STEAM education curriculum pattern, it is expected to be one of the important foundations in facing the industrial revolution 4.0 and being able to compete in the future.

Looking at various studies related to STEM, and the existence of Indonesia 4.0 policies, a synthesis of the various existing researches in basic education needs to be reviewed to obtain an overview of projects that have been developed by teachers and the adequacy of project development in the basic education curriculum. The systematic review study focuses on STEM learning research in the field of elementary education with a publication year starting from 2017 to 2020. The review is carried out on research articles that have been published nationally and have been accredited by the Ministry of Research and Technology / National Agency for Research and Development. Innovations. Journal indexation on a special page provided by the government is https://sinta.ristekbrin.go.id/. Sinta is an abbreviation of Science and Technology Index. It is a portal that contains the measurement of the performance of writers, researchers, authors, the development of the performance of science and technology journals and institutions in Indonesia. Sinta 
has the main advantage that it can automatically index works that have been indexed in Google Scholar, Scopus, InaSTI, and IPI (Indonesia Publication Index) (Ministry of Research and Technology /National Agency for Research and Innovation, 2017). The systematic review is the process of reviewing scientific articles carried out in a structured and planned manner to improve understanding in reviewing and summarizing research evidence (Hariyati, 2010). This systematic review aims to describe the development of basic education STEM research in Indonesia and the various types of learning projects developed based on the basic education curriculum. These results are expected to be an illustration and inspire teachers in conducting STEM learning with a variety of potential student projects.

\section{METHODS}

A systematic review is one of the research methods to identify, evaluate, interpret all research results related to certain research questions, certain topics, or phenomena of concern. The systematic review research method has two techniques in obtaining results from the literature findings to present a comprehensive fact. The two techniques are quantitative techniques (meta-analysis) and qualitative techniques (meta-synthesis). In this study, the technique is qualitative (metasynthesis). Meta-synthesis is a technique in summarizing research results to obtain new theories or concepts, or a deeper and more comprehensive level of understanding (Siswanto, 2010; Wahono, 2015).

The data that has been found is then analyzed using the Preferred Reporting Items for Systematic Review and Meta-Analysis (PRISMA) method which is carried out systematically according to the correct research stages by describing the facts and then doing the analysis stage (meta-synthesis). The stages in the implementation of a systematic review are very well planned and systematic so that research with this method has differences from methods that only convey literature studies. The implementation of systematic review research has several steps consisting of (1) identifying research questions, (2) developing research protocols, (3) determining the location of the search area database, (4) selecting relevant research results, (5) selection criteria, (6) data extraction, (7) synthesizing results using meta-synthesis, and (8) presenting results. The detailed explanation is shown in Table 1. 
Table 1. Stages in the analysis using PRISMA

\begin{tabular}{|c|c|c|}
\hline No & Stages & Description \\
\hline 1 & $\begin{array}{l}\text { Identifying } \\
\text { research } \\
\text { questions }\end{array}$ & $\begin{array}{l}\text { Researchers identify research questions to be used as a reference } \\
\text { in searching for article data to avoid unqualified article sources. }\end{array}$ \\
\hline 2 & $\begin{array}{l}\text { Developing } \\
\text { research } \\
\text { protocols }\end{array}$ & Researchers find published research related to STEM education. \\
\hline 3 & $\begin{array}{l}\text { Determining } \\
\text { the location of } \\
\text { the search area } \\
\text { database }\end{array}$ & $\begin{array}{l}\text { Researchers set limits in the search for scientific articles by } \\
\text { using predetermined keywords. }\end{array}$ \\
\hline 4 & $\begin{array}{l}\text { Selecting } \\
\text { relevant } \\
\text { research results }\end{array}$ & $\begin{array}{l}\text { The data is accessed according to the topics that have been } \\
\text { determined in this research process and selected based on the } \\
\text { criteria that have been determined by the researcher. }\end{array}$ \\
\hline 5 & Selection criteria & $\begin{array}{l}\text { Researchers select scientific articles from the search results and } \\
\text { group them for further sorting in the next stage. }\end{array}$ \\
\hline 6 & Data extraction & $\begin{array}{l}\text { Research journals that match the inclusion criteria were } \\
\text { collected and summarized in the form of a table containing the } \\
\text { research title, name of the researcher, location, research method, } \\
\text { STEM concept, level, theme, advantages, disadvantages, and } \\
\text { potential for further development. The table is to further clarify } \\
\text { the researcher in analyzing the data further. }\end{array}$ \\
\hline 7 & $\begin{array}{l}\text { Synthesizing } \\
\text { results using } \\
\text { meta-synthesis }\end{array}$ & $\begin{array}{l}\text { Researchers group important data that will be studied in depth } \\
\text { regarding the content, facts, and information contained in the } \\
\text { research article which will be concluded to answer research } \\
\text { questions. }\end{array}$ \\
\hline 8 & $\begin{array}{l}\text { Presenting } \\
\text { results }\end{array}$ & $\begin{array}{l}\text { The data that has been analyzed is then presented in tabular } \\
\text { form including the title of the study, the name of the researcher, } \\
\text { the theme of thematic learning at the elementary school level, } \\
\text { basic competencies, grade level, and the type of project. }\end{array}$ \\
\hline
\end{tabular}

The primary sources in this study are various literatures on STEM basic education contained in scientific journals indexed on the SINTA indexing page ranked 1-6. The search for data sources is carried out in each edition that has been published by scientific journals with the last four years of publication (2017- 
2020). The search for data sources was carried out from November 26, 2020, to December 16, 2020. The data collection technique used documentation, namely document collection on the SINTA page with predetermined criteria according to the criteria of the research subject. The researcher used a process framework to include an article for further review as shown in Figure 1.

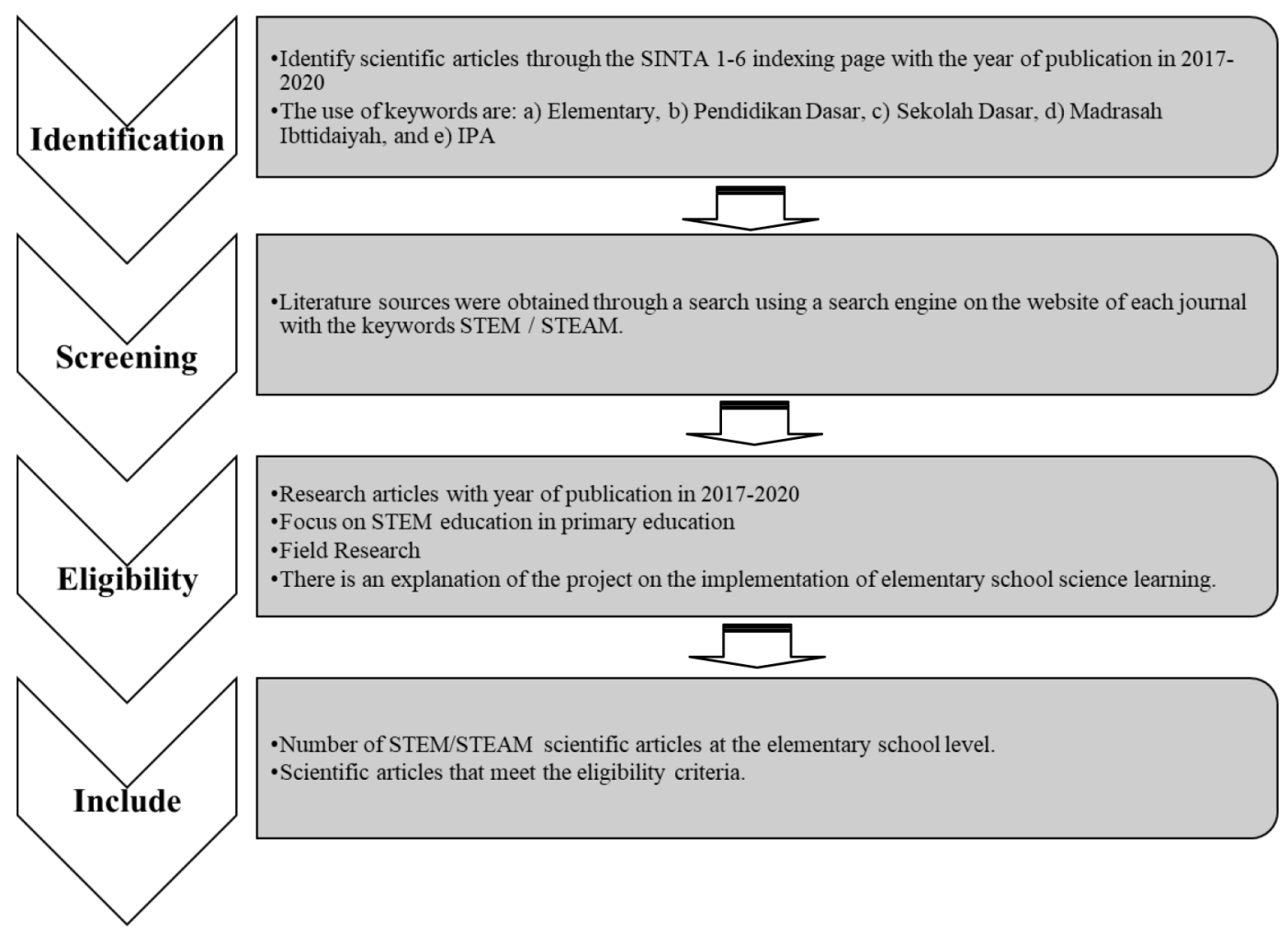

Figure 1. Process framework for determining the scientific articles to be reviewed

\section{RESULTS AND DISCUSSION}

In the initial stage of this research, the researchers set the Sinta indexing page ranked 1-6 with the year of publication in 2017-2020 as a database to find published literature in several scientific journals. Furthermore, the data search process begins by reading the abstracts in each literature to determine the suitability of the topic in this study. The initial findings are shown in Table 2. 
Table 2. Distribution of scientific articles on various rankings of Sinta that have the potential for further analysis

\begin{tabular}{cccccc}
\hline \multirow{2}{*}{$\begin{array}{c}\text { The Rank of } \\
\text { Journal }\end{array}$} & \multicolumn{2}{c}{ Number of scientific articles in the year of publication } & \multirow{2}{*}{ Total } \\
\cline { 2 - 5 } & $\mathbf{2 0 1 7}$ & $\mathbf{2 0 1 8}$ & $\mathbf{2 0 1 9}$ & $\mathbf{2 0 2 0}$ & \\
\hline Sinta $\mathbf{1}$ & 51 & 60 & 60 & 45 & 216 \\
\hline Sinta $\mathbf{2}$ & 166 & 148 & 164 & 93 & 571 \\
\hline Sinta 3 & 525 & 545 & 610 & 479 & 2159 \\
\hline Sinta 4 & 483 & 641 & 652 & 725 & 2501 \\
\hline Sinta 5 & 367 & 498 & 534 & 480 & 1879 \\
\hline Sinta $\mathbf{6}$ & 0 & 0 & 0 & 0 & 0 \\
\hline Total & $\mathbf{1 5 9 2}$ & $\mathbf{1 8 9 2}$ & $\mathbf{2 0 2 0}$ & $\mathbf{1 8 2 2}$ & $\mathbf{7 3 2 6}$ \\
\hline
\end{tabular}

Researchers carried out the screening process by reading the abstract details in scientific articles. The important point at this stage is to obtain a research study related to the topic of education in the STEM/STEAM field. Of the 7,326 articles, the researchers found 51 related articles. The distribution is shown in Figure 2. The highest gains for articles on this topic were obtained in scientific journals ranked at Sinta 3. Meanwhile, in 2017, the highest number of articles obtained in journals included in Sinta 5, which was only one article, while in 2020, the highest number of articles was obtained in journals with a rank of Sinta 4 as many as 9 articles. Overall, STEM-related topics in the journals indexed by Sinta have increased in number every year.

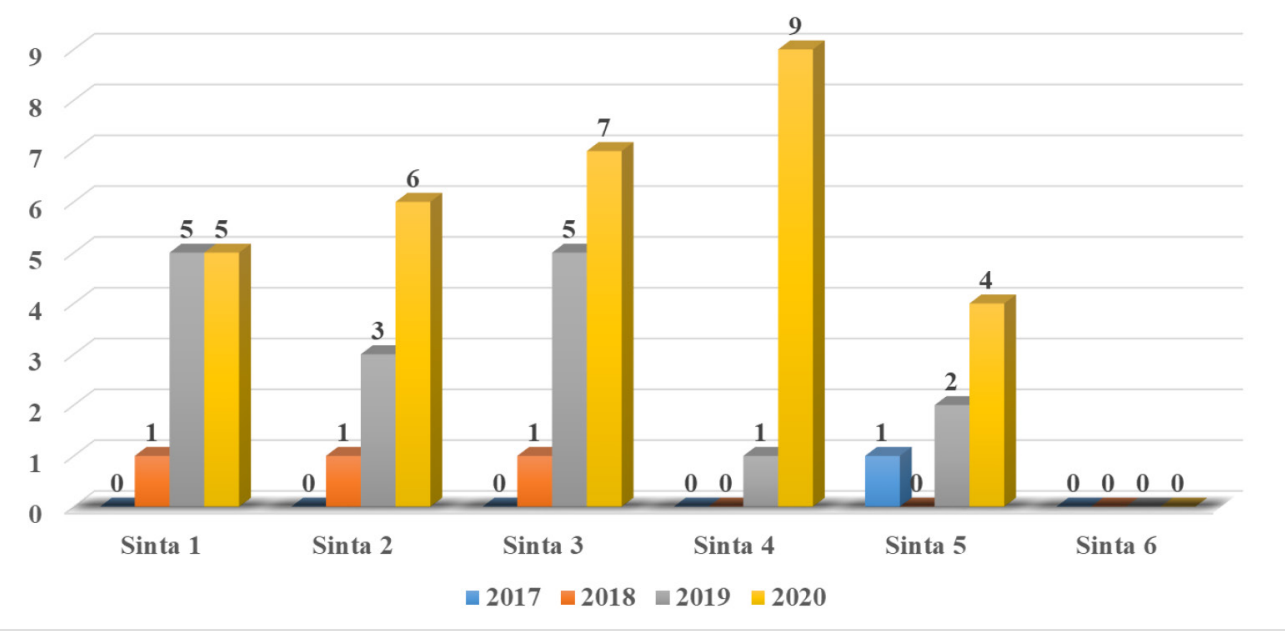

Figure 2. Distribution of research results on STEM education topics with the publication year 2017-2020 on the Sinta index. 
In 2017, research discussing STEM education has not been widely carried out. This shows how efforts to improve the quality of STEM education still need to be worked on. The results of further analysis on the existing 51 articles, can be seen in the distribution of research at the level of education. There are 17 STEM articles at the elementary level, 9 articles at the junior high school level, 13 articles discussing implementation in high school, 4 articles at the higher education level, and 8 articles with related themes outside the previous formal education level. Distribution based on education level is shown in Figure 3.

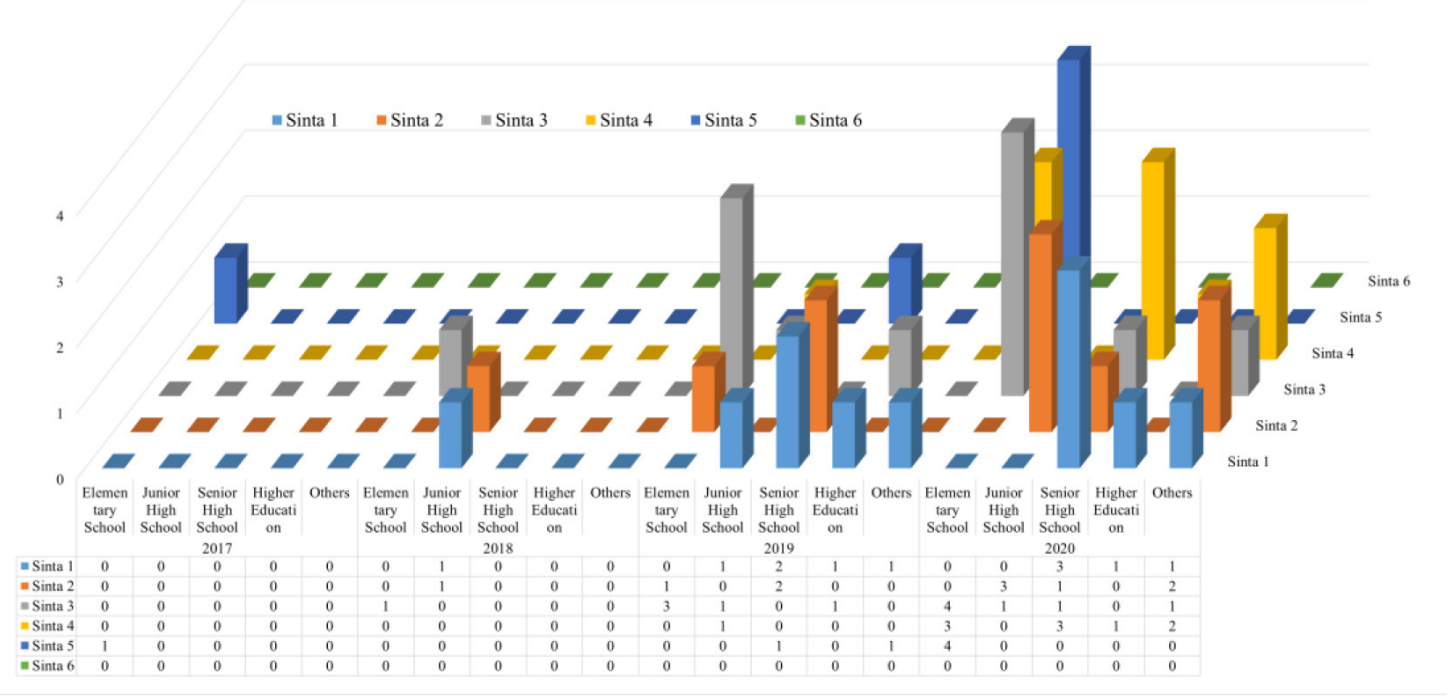

Figure 3. Distribution of scientific articles related to STEM Education at various levels of education

The results of data extraction that have been adjusted to the inclusion criteria show that 17 articles are basic education research that can be analyzed further. The 17 articles were obtained in various journals indexed by Sinta on the 2, 3, 4, and 5 rankings as shown in Figure 4. The detailed list of journals that match the criteria is shown in Table 3. 


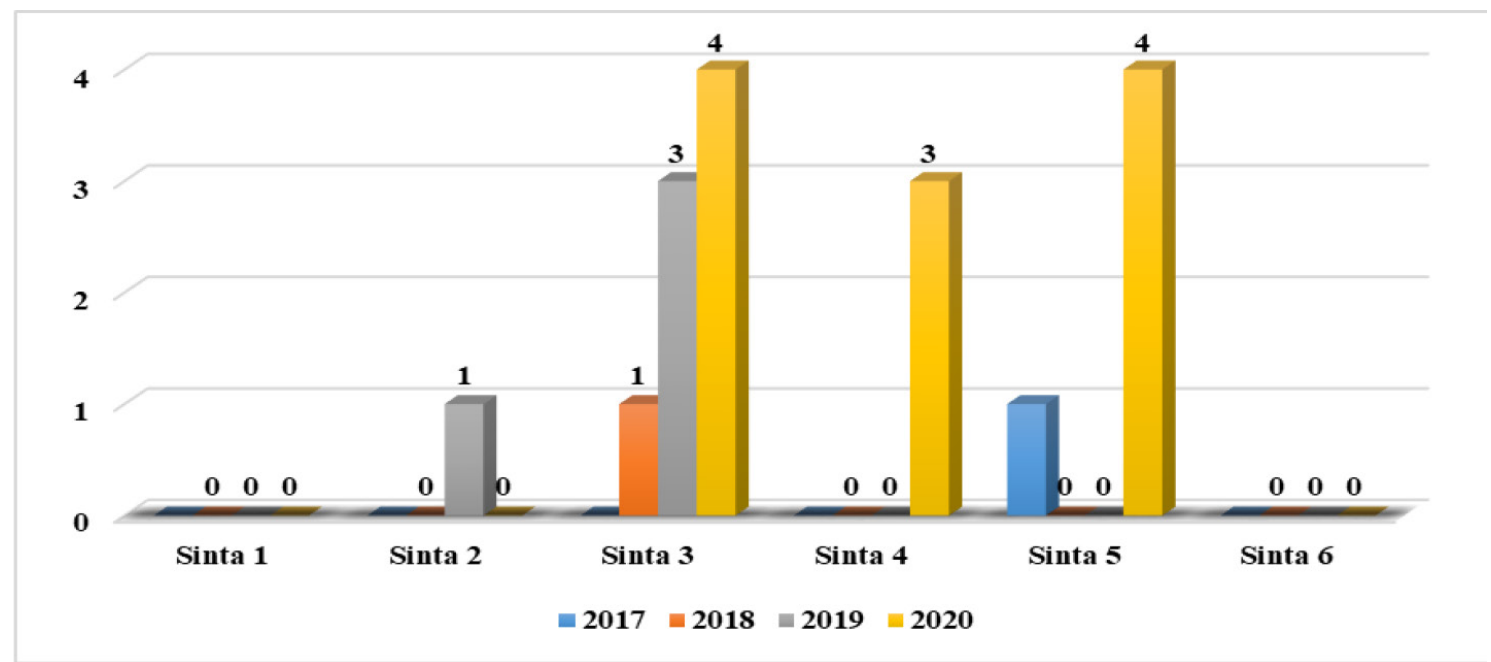

Figure 4. Distribution of obtaining scientific articles on STEM Education at the basic level in Sinta indexed journals

Table 3. Scientific Journals that match the criteria for the "include" stage in the PRISMA

\begin{tabular}{|c|c|c|c|c|}
\hline No & Journal & Title & $\begin{array}{c}\text { Authors \& } \\
\text { Year }\end{array}$ & Rank \\
\hline 1 & $\begin{array}{l}\text { Premiere } \\
\text { Educandum: } \\
\text { Jurnal } \\
\text { Pendidikan } \\
\text { Dasar dan } \\
\text { Pembelajaran }\end{array}$ & $\begin{array}{l}\text { Peningkatan sikap ilmiah dan prestasi belajar } \\
\text { menggunakan model Science, Technology, } \\
\text { Engineering, and Mathematics di kelas V MIM } \\
\text { Kramat [Improving scientific attitudes and } \\
\text { learning achievement using the Model of Science, } \\
\text { Technology, Engineering, and Mathematics in } \\
\text { class V MIM Kramat] }\end{array}$ & $\begin{array}{l}\text { (Septine } e t \\
\text { al., 2019) }\end{array}$ & Sinta 2 \\
\hline 2 & $\begin{array}{l}\text { Elementary } \\
\text { School } \\
\text { Journal }\end{array}$ & $\begin{array}{l}\text { Pembelajaran Kooperatif Student STEAM } \\
\text { Achievement dalam Upaya Meningkatkan Hasil } \\
\text { Belajar PKN Siswa Kelas V SD Negeri } 168060 \\
\text { Kota Tebing Tinggi [Cooperative Learning } \\
\text { Student STEAM Achievement in an Effort to } \\
\text { Improve PKN Learning Outcomes for Fifth Grade } \\
\text { Students at SD Negeri } 168060 \text { Kota Tebing } \\
\text { Tinggi] }\end{array}$ & $\begin{array}{l}\text { (Soldiana, } \\
2018 \text { ) }\end{array}$ & Sinta 3 \\
\hline
\end{tabular}




\begin{tabular}{|c|c|c|c|c|}
\hline No & Journal & Title & $\begin{array}{c}\text { Authors \& } \\
\text { Year }\end{array}$ & Rank \\
\hline 3 & $\begin{array}{l}\text { Profesi } \\
\text { Pendidikan } \\
\text { Dasar }\end{array}$ & $\begin{array}{l}\text { Pengembangan Bahan Ajar Berbasis STEM } \\
\text { (Science, Technology, Engineering, and } \\
\text { Mathematics) Materi Kelistrikan untuk Sekolah } \\
\text { Dasar [Development of STEM-Based Teaching } \\
\text { Materials (Science, Technology, Engineering, } \\
\text { and Mathematics) Electrical Materials for } \\
\text { Elementary Schools] }\end{array}$ & $\begin{array}{l}\text { (Yuanita } \\
\text { \& Kurnia, } \\
\text { 2019) }\end{array}$ & Sinta 3 \\
\hline 4 & $\begin{array}{l}\text { Jurnal Inovasi } \\
\text { Pendidikan } \\
\text { Dasar }\end{array}$ & $\begin{array}{l}\text { The Development of STEM Integrated } \\
\text { Encyclopedia (Science, Technology, Engineering, } \\
\text { Mathematics) as Enrichment for Students in } \\
\text { Elementary Schools }\end{array}$ & $\begin{array}{l}\text { (Erviana, } \\
\text { 2019) }\end{array}$ & Sinta 3 \\
\hline 5 & $\begin{array}{l}\text { Mimbar } \\
\text { Sekolah Dasar }\end{array}$ & $\begin{array}{l}\text { Effect of STEM-based Learning on the Cognitive } \\
\text { Skills Improvement }\end{array}$ & $\begin{array}{l}\text { (Firdaus et } \\
\text { al., 2019) }\end{array}$ & Sinta 3 \\
\hline 6 & $\begin{array}{l}\text { Jurnal Ilmiah } \\
\text { Sekolah Dasar }\end{array}$ & $\begin{array}{l}\text { Pengembangan Media Pembelajaran Kayaku } \\
\text { (Kayanya Alam Negeriku) Berbasis STEM Kelas } \\
\text { IV Sekolah Dasar [Development of Kayaku } \\
\text { (Kayanya Alam Negeri) Learning Media Based } \\
\text { on STEM Class IV Elementary School] }\end{array}$ & $\begin{array}{l}\text { (Maula \& } \\
\text { Fatmawati, } \\
\text { 2020) }\end{array}$ & Sinta 3 \\
\hline 7 & $\begin{array}{l}\text { Jurnal Ilmiah } \\
\text { Sekolah Dasar }\end{array}$ & $\begin{array}{l}\text { Rubrik Asesmen Kinerja Berpikir Kritis pada } \\
\text { Pembelajaran STEM dengan Media Lightning } \\
\text { Tamiya Car [Critical Thinking Performance } \\
\text { Assessment Rubric in STEM Learning with } \\
\text { "Lightning Tamiya Car" Media] }\end{array}$ & $\begin{array}{l}\text { (Kurniasih } \\
\text { et al., 2020) }\end{array}$ & Sinta 3 \\
\hline 8 & $\begin{array}{l}\text { Jurnal Ilmiah } \\
\text { Sekolah Dasar }\end{array}$ & $\begin{array}{l}\text { Project-Based Learning } \\
\text { Based on }\end{array}$ & $\begin{array}{l}\text { (Lely et al., } \\
\text { 2020) }\end{array}$ & Sinta 3 \\
\hline 9 & $\begin{array}{l}\text { JMIE (Journal } \\
\text { of Madrasah } \\
\text { Ibtidaiyah } \\
\text { Education) }\end{array}$ & $\begin{array}{l}\text { Project-Based Learning-Literacy in Improving } \\
\text { Students' Mathematical Reasoning Abilities in } \\
\text { Elementary Schools }\end{array}$ & $\begin{array}{l}\text { (Abidin } \text { et } \\
\text { al., 2020) }\end{array}$ & Sinta 3 \\
\hline 10 & $\begin{array}{l}\text { Jurnal } \\
\text { Fundadikdas } \\
\text { (Fundamental } \\
\text { Pendidikan } \\
\text { Dasar) }\end{array}$ & $\begin{array}{l}\text { Pengembangan Instrumen Penilaian Sikap } \\
\text { pada Pembelajaran STEM dengan Media } \\
\text { Perahu Bertenaga Uap di Kelas V Sekolah } \\
\text { Dasar [Development of Attitude Assessment } \\
\text { Instruments in STEM Learning with Steam- } \\
\text { Powered Boat Media in Class V Elementary } \\
\text { School] }\end{array}$ & $\begin{array}{l}\text { (Sabillah, } \\
\text { 2020) }\end{array}$ & Sinta 4 \\
\hline
\end{tabular}




\begin{tabular}{|c|c|c|c|c|}
\hline No & Journal & Title & $\begin{array}{c}\text { Authors \& } \\
\text { Year }\end{array}$ & Rank \\
\hline 11 & $\begin{array}{l}\text { Jurnal } \\
\text { Fundadikdas } \\
\text { (Fundamental } \\
\text { Pendidikan } \\
\text { Dasar) }\end{array}$ & $\begin{array}{l}\text { Pengembangan LKPD Berbasis STEM pada } \\
\text { Materi IPA Tema } 7 \text { Subtema } 1 \text { Kelas V Sekolah } \\
\text { Dasar [Development of STEM-Based Student } \\
\text { Worksheets on Science Materials Theme } 7 \text { Sub- } \\
\text { theme } 1 \text { Grade V Elementary School] }\end{array}$ & $\begin{array}{l}\text { (Febriyanti } \\
\text { \& Maryani, } \\
\text { 2020) }\end{array}$ & Sinta 4 \\
\hline 12 & $\begin{array}{l}\text { Jurnal } \\
\text { Pendidikan } \\
\text { Dasar }\end{array}$ & $\begin{array}{l}\text { Peningkatan Keterampilan Berhitung Siswa } \\
\text { Melalui Media Kotak Ajaib Berbasis STEM } \\
\text { pada Materi Konsep Penjumlahan [Increasing } \\
\text { Students' Counting Skills Through STEM-Based } \\
\text { Magic Box Media on Addition Concept Material] }\end{array}$ & $\begin{array}{l}\text { (Twiningsih } \\
\text { \& Sayekti, } \\
\text { 2020) }\end{array}$ & Sinta 4 \\
\hline 13 & $\begin{array}{l}\text { International } \\
\text { Journal of } \\
\text { Elementary } \\
\text { Education }\end{array}$ & $\begin{array}{l}\text { Electrical Tandem Roller (ETR) Media for } 4 C \\
\text { Capabilities Based Stem Learning Elementary } \\
\text { Schools }\end{array}$ & $\begin{array}{l}\text { la } e t \\
\text { b) }\end{array}$ & Sinta 5 \\
\hline 14 & $\begin{array}{l}\text { Jurnal Ilmiah } \\
\text { Pendidikan } \\
\text { Dasar }\end{array}$ & $\begin{array}{l}\text { Desain Pembelajaran STEM Berdasarkan } \\
\text { Kemampuan 4C di Sekolah Dasar [STEM } \\
\text { Learning Design Based on } 4 C \text { Ability in } \\
\text { Elementary School] }\end{array}$ & $\begin{array}{l}\text { (Oktapiani } \\
\text { \& Hamdu, } \\
\text { 2020) }\end{array}$ & Sinta 5 \\
\hline 15 & $\begin{array}{l}\text { Jurnal } \\
\text { DIDIKA: } \\
\text { Wahana } \\
\text { Ilmiah } \\
\text { Pendidikan } \\
\text { Dasar }\end{array}$ & $\begin{array}{l}\text { Pengembangan Soal Tes Tertulis Berbasis } \\
\text { STEM dengan Pemodelan Rasch Di Sekolah } \\
\text { Dasar [Development of STEM-Based Written Test } \\
\text { Questions with Rasch Modeling in Elementary } \\
\text { School] }\end{array}$ & $\begin{array}{l}\text { (Rahmat et } \\
\text { al., 2020) }\end{array}$ & Sinta 5 \\
\hline 16 & $\begin{array}{l}\text { Pendas: } \\
\text { Jurnal Ilmiah } \\
\text { Pendidikan } \\
\text { Dasar }\end{array}$ & $\begin{array}{l}\text { Pendekatan Science, Technology, Engineering, } \\
\text { and Mathematics (STEM) Sebagai Alternatif } \\
\text { dalam Mengembangakan Minat Belajar Peserta } \\
\text { Didik Sekolah Dasar [Science, Technology, } \\
\text { Engineering, and Mathematics (STEM) } \\
\text { Approaches as Alternatives in Developing } \\
\text { Learning Interests of Elementary School } \\
\text { Students] }\end{array}$ & $\begin{array}{l}\text { (Sukmana, } \\
\text { 2017) }\end{array}$ & Sinta 5 \\
\hline 17 & $\begin{array}{l}\text { Jurnal Kajian } \\
\text { Pendidikan } \\
\text { Dasar }\end{array}$ & $\begin{array}{l}\text { Meningkatkan Pemahaman Konsep Matematika } \\
\text { Menggunakan Pendekatan STEAM (Science, } \\
\text { Technology, Engineering, Arts and Mathematics) } \\
\text { Berbasis Daring [Improving Understanding of } \\
\text { Mathematical Concepts Using an Online-Based } \\
\text { STEAM (Science, Technology, Engineering, Arts } \\
\text { and Mathematics) Approach] }\end{array}$ & $\begin{array}{l}\text { (Oktaviani } \\
\text { et al., 2020) }\end{array}$ & Sinta 5 \\
\hline
\end{tabular}


Based on the 17 articles, a further analysis process was carried out to determine the types of learning projects contained in each of these articles. Researchers found as many as 7 scientific articles that describe the types of projects implemented in learning as shown in Table 4.

Table 4. Types of learning projects found in scientific articles

\begin{tabular}{|c|c|c|c|c|c|c|}
\hline No. & $\begin{array}{l}\text { Authors, } \\
\text { Year }\end{array}$ & $\begin{array}{l}\text { Research } \\
\text { Design }\end{array}$ & Projects & Grade & Theme & Project Theme \\
\hline 1. & $\begin{array}{l}\text { (Septine et } \\
\text { al., 2019) }\end{array}$ & $\begin{array}{l}\text { Classroom } \\
\text { Action } \\
\text { Research }\end{array}$ & $\begin{array}{l}\text { Simple water } \\
\text { filtration }\end{array}$ & $\begin{array}{l}5^{\text {th }} \text { grade } \\
\text { of Islamic } \\
\text { elementary } \\
\text { school }\end{array}$ & $\begin{array}{l}\text { Theme 8: } \\
\text { groundwater } \\
\text { and surface } \\
\text { water }\end{array}$ & Environment \\
\hline 2. & $\begin{array}{l}\text { (Kurniasih } \\
\text { et al., 2020) }\end{array}$ & $\begin{array}{l}\text { Design-Based } \\
\text { Research }\end{array}$ & $\begin{array}{l}\text { Media of } \\
\text { Lightning } \\
\text { Tamiya Car }\end{array}$ & $\begin{array}{l}5^{\text {th }} \text { grade of } \\
\text { elementary } \\
\text { school }\end{array}$ & $\begin{array}{l}\text { Electrical } \\
\text { components }\end{array}$ & $\begin{array}{l}\text { Energy \& } \\
\text { Recreative } \\
\text { Product }\end{array}$ \\
\hline 3. & $\begin{array}{l}\text { (Maula \& } \\
\text { Fatmawati, } \\
\text { 2020) }\end{array}$ & $\begin{array}{l}\text { Research \& } \\
\text { Development }\end{array}$ & $\begin{array}{l}\text { Interactive } \\
\text { media } \\
\text { developed } \\
\text { using Lectora } \\
\text { inspire App }\end{array}$ & $\begin{array}{l}5^{\text {th }} \text { grade of } \\
\text { elementary } \\
\text { school }\end{array}$ & $\begin{array}{l}\text { Theme 9: } \\
\text { natural } \\
\text { resources and } \\
\text { energy }\end{array}$ & Energy \\
\hline 4. & $\begin{array}{l}\text { (Erviana, } \\
\text { 2019) }\end{array}$ & $\begin{array}{l}\text { Research \& } \\
\text { Development }\end{array}$ & $\begin{array}{l}\text { Media of } \\
\text { Encyclopedia }\end{array}$ & $\begin{array}{l}3^{\text {rd }} \text { grade of } \\
\text { elementary } \\
\text { school }\end{array}$ & $\begin{array}{l}\text { Thematic } \\
\text { sub-theme } 2 \\
\text { learning } 3 \text { : } \\
\text { energy change }\end{array}$ & Energy \\
\hline 5. & $\begin{array}{l}\text { (Sabillah, } \\
\text { 2020) }\end{array}$ & $\begin{array}{l}\text { Educational } \\
\text { Design } \\
\text { Research } \\
\text { (EDR) } \\
\text { method }\end{array}$ & $\begin{array}{l}\text { Steam } \\
\text { Powered } \\
\text { Boat }\end{array}$ & $\begin{array}{l}5^{\text {th }} \text { grade of } \\
\text { elementary } \\
\text { school }\end{array}$ & $\begin{array}{l}\text { Material effect } \\
\text { of heat on } \\
\text { temperature }\end{array}$ & $\begin{array}{l}\text { Energy \& } \\
\text { Recreative } \\
\text { Product }\end{array}$ \\
\hline 6. & $\begin{array}{l}\text { (Oktapiani } \\
\text { \& Hamdu, } \\
\text { 2020) }\end{array}$ & $\begin{array}{l}\text { Qualitative } \\
\text { research } \\
\text { based on } \\
\text { Focus Group } \\
\text { Discussion } \\
\text { (FGD) }\end{array}$ & $\begin{array}{l}\text { Tandem } \\
\text { Roller Car }\end{array}$ & $\begin{array}{l}6^{\text {th }} \text { grade of } \\
\text { elementary } \\
\text { school }\end{array}$ & $\begin{array}{l}\text { Simple } \\
\text { Electrical } \\
\text { Component } \\
\text { Material }\end{array}$ & $\begin{array}{l}\text { Energy \& } \\
\text { Recreative } \\
\text { Product }\end{array}$ \\
\hline 7. & $\begin{array}{l}\text { (Cahyana et } \\
\text { al., 2020) }\end{array}$ & $\begin{array}{l}\text { Qualitative } \\
\text { research } \\
\text { based on } \\
\text { Focus Group } \\
\text { Discussion } \\
\text { (FGD) }\end{array}$ & $\begin{array}{l}\text { Media of } \\
\text { Electrical } \\
\text { Tandem } \\
\text { Roller }\end{array}$ & $\begin{array}{l}6^{\text {th }} \text { grade of } \\
\text { elementary } \\
\text { school }\end{array}$ & $\begin{array}{l}\text { Electrical } \\
\text { Components }\end{array}$ & $\begin{array}{l}\text { Energy \& } \\
\text { Recreative } \\
\text { Product }\end{array}$ \\
\hline
\end{tabular}


The implementation of the STEM approach in learning is carried out to equip students to develop various skills, especially collaboration, effective communication, thoroughness, curiosity, creativity, systematic thinking, and problem-solving (Dugger, 2010; Seage \& Türegün, 2020). However, STEM education has not been consistently understood for its application at the school level (Wang, Moore, Roehrig, \& Park, 2011). Integrative STEM teaching needs to be developed and implemented. Teachers must be able to design strategies and types of projects that suit students' interests, as well as facilitate optimizing students' skills (Tseng et al., 2013). The application of STEM in the classroom is a challenge to be implemented in various subjects in the school curriculum (Imaduddin et al., 2021). There are six steps of STEM implementation with a project-based learning model as developed by The George Lucas Educational Foundation. The steps for teaching STEM are shown in Figure 5 (Wahyu, 2018).

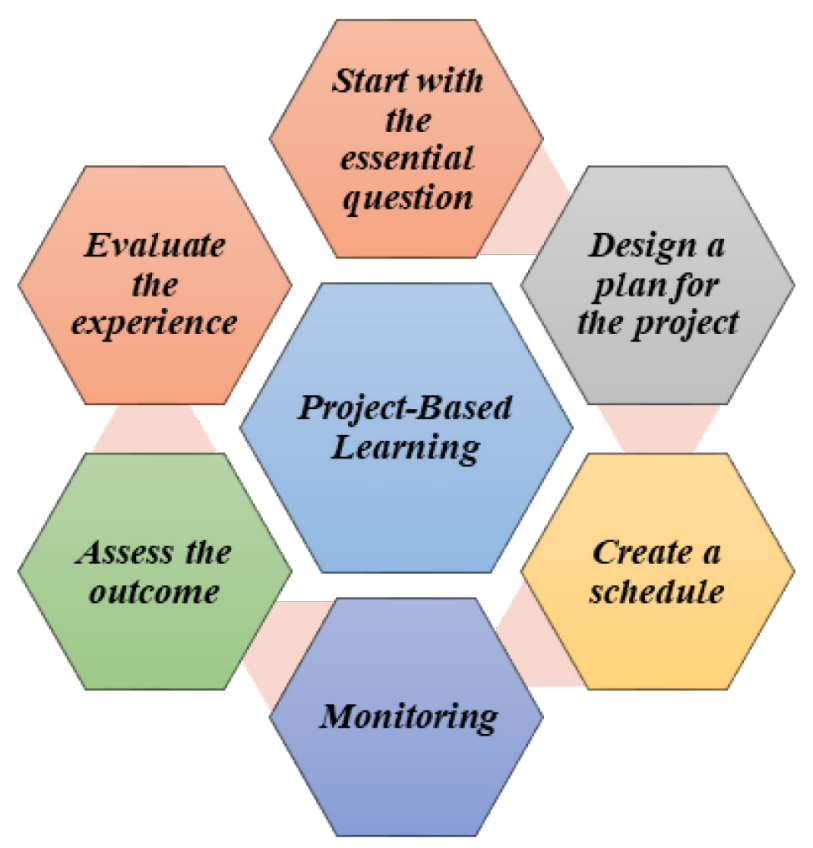

Figure 5. The Procedure of Project-Based Learning for Teaching STEM (Wahyu, 2018)

STEM learning designs that produce learning projects are by designing Electrical Tandem Roller (ETR) products so that students can understand electrical components, can train cognitive, manipulative, affective, and can make the learning process more fun (Cahyana et al., 2020; Oktapiani \& Hamdu, 2020) and train critical 
thinking skills, creativity, collaboration, and communication (Cahyana et al., 2020). This media was modified by Cahyana (2020) as shown in Figure 6. The media of a steam-powered boat was also used as a project in STEM learning with a focus on studying the effect of heat on temperature. In addition, this project is used as part of the assessment of student attitudes so that it can be used as an evaluation for further learning (Sabillah, 2020).

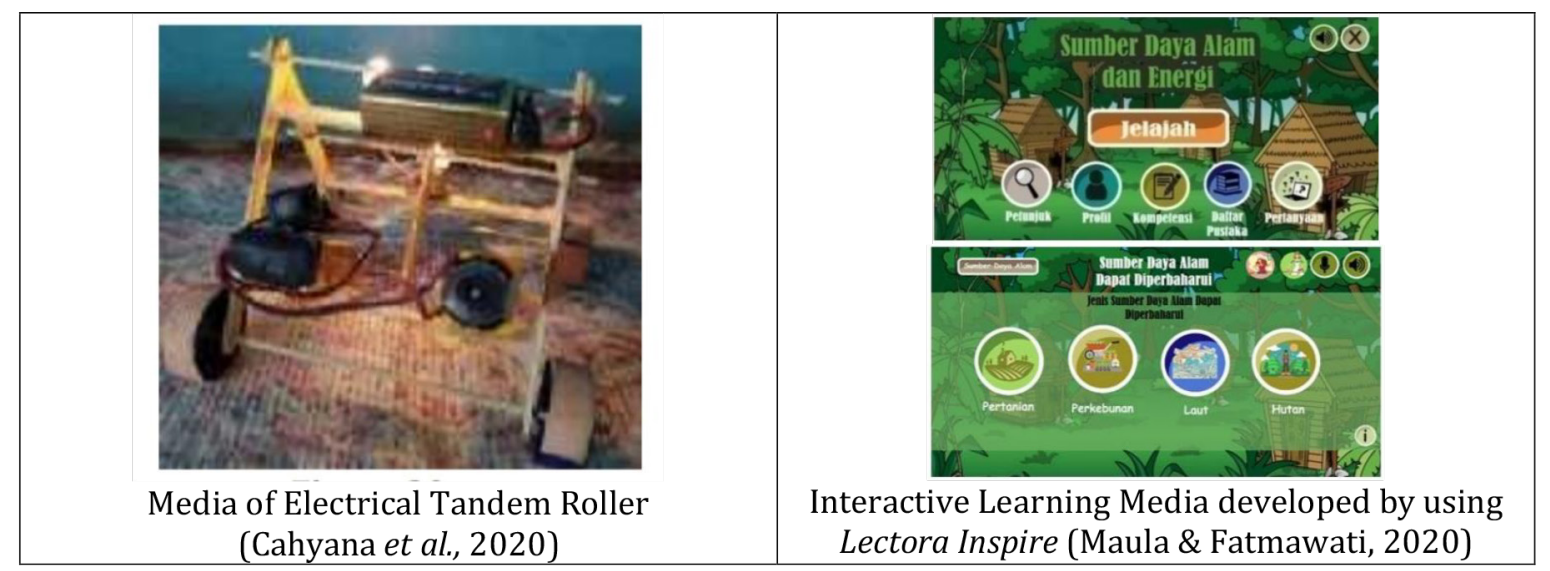

Figure 6. Some examples of students' learning projects

The Encyclopedia media learning project is also a product that can be produced from STEM-based learning to improve students' critical and creative thinking skills (Erviana, 2019). Learning projects can be used as a medium for critical thinking performance assessment rubrics. For example, in a project that uses simple materials such as used bottle caps to make an electric-powered toy car (Lightning Tamiya Car/LTC) (Kurniasih et al., 2020). The LTC project can be used as a benchmark for each individual's ability so that it can develop students' critical thinking skills in STEM-based learning. In addition to the types of projects that are categorized as energy types, there are also types of recreational learning projects that produce interactive media using the Lectora Inspire application as shown in Figure 6. This media displays various natural and energy resources that exist in Indonesia so that students can understand and accept the material. easily and give a pleasant impression to students during the learning process (Maula \& Fatmawati, 2020). Another type of project is aimed at groundwater and surface water materials that can produce a simple water filtration product so that students can understand the process of filtering water to produce clear water by applying a STEM-based learning 
process (Septine et al., 2019). From several projects that have been identified and refer to the summary shown in Table 4., it is known that the trend of developing STEM projects in Indonesia is still within the scope of Natural Science subjects with the type of project in the energy category at the upper-grade level $(4,5$, and 6$)$.

The potential for STEM-based learning in basic education has been implemented abroad such as in Turkey. A study on the application of STEM learning in grade III elementary schools in Turkey with the teaching of "Let's Get to Know the Problem" (Ultay et al., 2020). This study shows that students are trained to be able to solve problems according to the learning theme which will produce products in the form of boats and raincoats as shown in Figure 7. These products are produced from various ideas and creativity from students. The potential of the project is already seen in the "Road Map" material for grades III-V elementary school, students are faced with challenges such as developing weather predictions, designing future transportation, and saving water from one of our most valuable resources on earth. As for grade VI, students explore topics such as amusement parks, human impacts on climate, communication, water quality, and natural hazards. In the subjects of science and mathematics, the theme of the Map for grade VI elementary school is focused on the human impact on the climate as a whole. This project requires students to analyze aspects of human activities that have contributed to and caused global climate change. The topic of Amusement of the Future will motivate students to design prototypes of future amusement parks so that students can develop emergency awareness and prepare innovations to deal with the consequences of natural hazards (Gladden, 2008). The development of STEM into STEAM by integrating "Arts" has also been introduced through experimental activities of making rainbows from sugar-coating, rainbow rain, and the ability of plants to absorb water in grades I-III with Science and Mathematics subjects by producing a product in Figure 8. The results of these experiments can have a positive impact on students and are motivated to learn with STEAM-based learning (Nurwulan, 2020). STEAM learning is applied to grades I-VI in the main subject, namely Science which will be integrated with other subjects such as Arts, English, or others that have been adapted to materials that are truly appropriate so that learning can be achieved properly (Rahmawati, 2020). Several products can be produced from STEAM learning that has been applied at every grade level, such as making food products during online learning, designing human skeletons, and creating geometry structures (Figure 9.). 

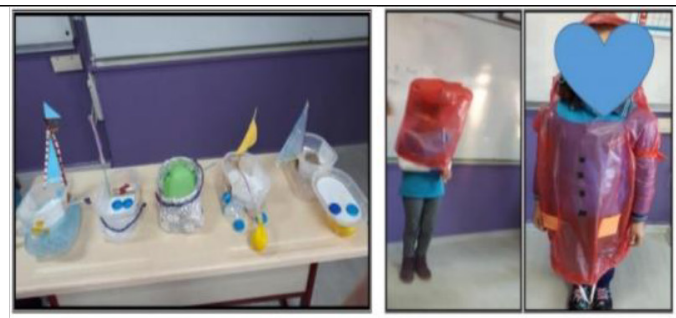

The product results in project-based learning are boat toys and raincoats (Ultay et al., 2020)
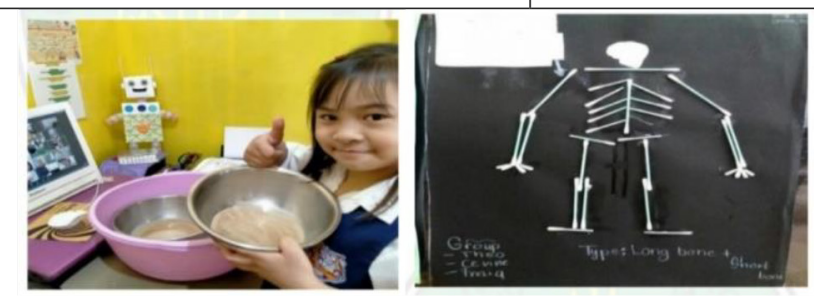

Food, Human Skeleton, and Geometry projects that have the potential to be implemented in STEM learning (Rahmawati, 2020)

Figure 9. Several projects for the lower grades of elementary school.

\section{The Potential for Alternative Project-Based Learning Procedures with STEM Approach}

STEM learning can be applied and developed at the lower grade level by integrating various subjects that can support the application of STEM components according to existing topics and phenomena to train and develop students' critical thinking skills and can prepare generations to face the challenges of the 21st century. Referring to the project-based learning procedure, several design projections may be made for the entire elementary school level both lower and upper levels on the topic of recreation, environment, and energy. Recreational learning activities can be applied by an educator so that students do not feel bored because recreational learning is learning that creates a fun and enjoyable classroom atmosphere. Table 5 shows the potential for STEM learning procedures in the lower and upper grades of elementary school. 
Table 5. Potential project-based learning procedures with a STEM approach with a recreational orientation

\begin{tabular}{|c|c|c|c|c|}
\hline \multirow[t]{2}{*}{$\begin{array}{l}\text { Project- } \\
\text { Based } \\
\text { Learning } \\
\text { Procedure }\end{array}$} & \multicolumn{2}{|c|}{$\begin{array}{c}\text { Theme } 5 \text { My Experiences: Bridge } \\
\text { Construction Project (Class II) } \\
\text { (modified from Hinton, 2020) }\end{array}$} & \multicolumn{2}{|c|}{$\begin{array}{l}\text { Theme } 8 \text { changes in the shape of } \\
\text { objects: Ice Cream Projects } \\
\text { (Class V) (modified from Agus, } \\
2018 \text { ) }\end{array}$} \\
\hline & $\begin{array}{l}\text { Teacher's } \\
\text { Activities }\end{array}$ & $\begin{array}{l}\text { Students' } \\
\text { Activities }\end{array}$ & $\begin{array}{l}\text { Teacher's } \\
\text { Activities }\end{array}$ & $\begin{array}{l}\text { Students' } \\
\text { Activities }\end{array}$ \\
\hline $\begin{array}{l}\text { Identifying } \\
\text { the problem }\end{array}$ & $\begin{array}{l}\text { [1] The teacher } \\
\text { shows a video } \\
\text { about "rural } \\
\text { areas without } \\
\text { bridge } \\
\text { access" }\end{array}$ & $\begin{array}{l}\text { [1]Students } \\
\text { watch the } \\
\text { video and } \\
\text { analyze the } \\
\text { problem }\end{array}$ & $\begin{array}{l}\text { [1] The teacher } \\
\text { shows a } \\
\text { video about } \\
\text { "types of } \\
\text { changing } \\
\text { the shape of } \\
\text { objects" }\end{array}$ & $\begin{array}{l}\text { [1] Students } \\
\text { watch the } \\
\text { video and } \\
\text { analyze the } \\
\text { problem of } \\
\text { change of } \\
\text { form }\end{array}$ \\
\hline
\end{tabular}

\begin{tabular}{|c|c|c|c|c|}
\hline $\begin{array}{l}\text { Drafting } \\
\text { designs and } \\
\text { schedules }\end{array}$ & $\begin{array}{l}\text { [2] Students } \\
\text { are asked } \\
\text { to design a } \\
\text { bridge from } \\
\text { straws }\end{array}$ & $\begin{array}{l}\text { [2]Students look } \\
\text { for solutions } \\
\text { to these } \\
\text { problems by } \\
\text { designing } \\
\text { bridges from } \\
\text { straws }\end{array}$ & $\begin{array}{l}\text { [2] Students } \\
\text { are asked } \\
\text { to make ice } \\
\text { cream }\end{array}$ & $\begin{array}{l}\text { [2] Students } \\
\text { find } \\
\text { solutions } \\
\text { to these } \\
\text { problems } \\
\text { by making } \\
\text { ice cream } \\
\text { projects }\end{array}$ \\
\hline Monitoring & $\begin{array}{l}\text { [3] The teacher } \\
\text { accompanies } \\
\text { students in } \\
\text { completing } \\
\text { the product. }\end{array}$ & $\begin{array}{l}\text { [3] Students } \\
\text { determine } \\
\text { how many } \\
\text { straws } \\
\text { are used } \\
\text { to design } \\
\text { bridges so } \\
\text { that they } \\
\text { can support } \\
\text { objects }\end{array}$ & $\begin{array}{l}\text { [3] The teacher } \\
\text { assists } \\
\text { students in } \\
\text { completing } \\
\text { the product. }\end{array}$ & $\begin{array}{l}\text { [3] Students } \\
\text { determine } \\
\text { what } \\
\text { materials } \\
\text { are used to } \\
\text { make ice } \\
\text { cream }\end{array}$ \\
\hline
\end{tabular}




\begin{tabular}{|c|c|c|c|c|}
\hline \multirow[t]{2}{*}{$\begin{array}{l}\text { Project- } \\
\text { Based } \\
\text { Learning } \\
\text { Procedure }\end{array}$} & \multicolumn{2}{|c|}{$\begin{array}{l}\text { Theme } 5 \text { My Experiences: Bridge } \\
\text { Construction Project (Class II) } \\
\text { (modified from Hinton, 2020) }\end{array}$} & \multicolumn{2}{|c|}{$\begin{array}{c}\text { Theme } 8 \text { changes in the shape of } \\
\text { objects: Ice Cream Projects } \\
\text { (Class V) (modified from Agus, } \\
\text { 2018) }\end{array}$} \\
\hline & $\begin{array}{l}\text { Teacher's } \\
\text { Activities }\end{array}$ & $\begin{array}{l}\text { Students' } \\
\text { Activities }\end{array}$ & $\begin{array}{l}\text { Teacher's } \\
\text { Activities }\end{array}$ & $\begin{array}{l}\text { Students' } \\
\text { Activities }\end{array}$ \\
\hline $\begin{array}{l}\text { Assessing } \\
\text { results }\end{array}$ & $\begin{array}{l}\text { [4] The teacher } \\
\text { accompanies } \\
\text { students in } \\
\text { conducting } \\
\text { experiments. }\end{array}$ & $\begin{array}{l}\text { [4]Students } \\
\text { conduct } \\
\text { experiments } \\
\text { on making } \\
\text { bridges and } \\
\text { can see the } \\
\text { work of other } \\
\text { groups }\end{array}$ & $\begin{array}{l}\text { [4] The teacher } \\
\text { accompanies } \\
\text { the students } \\
\text { in making ice } \\
\text { cream }\end{array}$ & $\begin{array}{l}\text { [4] Students } \\
\text { conduct } \\
\text { experiments } \\
\text { on making } \\
\text { ice cream } \\
\text { and can see } \\
\text { the work of } \\
\text { other groups }\end{array}$ \\
\hline $\begin{array}{l}\text { Evaluating } \\
\text { experiences }\end{array}$ & $\begin{array}{l}\text { [5] The teacher } \\
\text { provides } \\
\text { input and } \\
\text { provides } \\
\text { solutions } \\
\text { to the } \\
\text { difficulties } \\
\text { found by } \\
\text { students. }\end{array}$ & $\begin{array}{l}\text { [5]Students } \\
\text { present the } \\
\text { results of the } \\
\text { experiment. }\end{array}$ & $\begin{array}{l}\text { [5] The teacher } \\
\text { provides } \\
\text { comments } \\
\text { and provides } \\
\text { solutions to }\end{array}$ & $\begin{array}{l}\text { [5] Students } \\
\text { present the } \\
\text { results of the } \\
\text { experiment. }\end{array}$ \\
\hline
\end{tabular}

Learning activities focused on environmental studies can be applied by an educator by utilizing the environment as a learning resource. Table 6 is a form of STEM learning procedure design with environmental topics in the lower and upper grades of elementary school. 
Table 6. The potential of project-based learning procedures with a STEM approach with an orientation to environmental understanding

\begin{tabular}{|c|c|c|c|c|}
\hline \multirow{2}{*}{$\begin{array}{l}\text { Project- } \\
\text { Based } \\
\text { Learning } \\
\text { Procedure }\end{array}$} & \multicolumn{2}{|c|}{$\begin{array}{c}\text { Theme } 2 \text { sub-theme } 1 \text { : making } \\
\text { webbing (Class } 2 \text { ) }\end{array}$} & \multicolumn{2}{|c|}{$\begin{array}{c}\text { Theme } 3 \text { sub-themes 1: Plant } \\
\text { growth (Grade VI) }\end{array}$} \\
\hline & $\begin{array}{l}\text { Teacher's } \\
\text { Activities }\end{array}$ & $\begin{array}{l}\text { Students' } \\
\text { Activities }\end{array}$ & $\begin{array}{l}\text { Teacher's } \\
\text { Activities }\end{array}$ & $\begin{array}{l}\text { Students' } \\
\text { Activities }\end{array}$ \\
\hline $\begin{array}{l}\text { Identifying } \\
\text { the problem }\end{array}$ & $\begin{array}{l}\text { [1] The } \\
\text { teacher asks } \\
\text { students to } \\
\text { understand } \\
\text { the various } \\
\text { leaves }\end{array}$ & $\begin{array}{l}\text { [1] Students } \\
\text { understand } \\
\text { the various } \\
\text { leaves }\end{array}$ & $\begin{array}{l}\text { [1] The teacher } \\
\text { asks students } \\
\text { to read the } \\
\text { story text } \\
\text { "West Java is } \\
\text { the largest } \\
\text { producer } \\
\text { of sprouted } \\
\text { seeds in } \\
\text { Indonesia" }\end{array}$ & $\begin{array}{l}\text { [1] Students } \\
\text { read the } \\
\text { story text } \\
\text { "West Java is } \\
\text { the largest } \\
\text { producer of } \\
\text { sprouts in } \\
\text { Indonesia" }\end{array}$ \\
\hline $\begin{array}{l}\text { Drafting } \\
\text { designs and } \\
\text { schedules }\end{array}$ & $\begin{array}{l}\text { [2] Students } \\
\text { are asked to } \\
\text { make plaits }\end{array}$ & $\begin{array}{l}\text { [2] Students find } \\
\text { solutions } \\
\text { to these } \\
\text { problems by } \\
\text { designing } \\
\text { bridges. } \\
\text { Students } \\
\text { make } \\
\text { webbing }\end{array}$ & $\begin{array}{l}\text { [2] Students } \\
\text { are asked } \\
\text { to design } \\
\text { or design } \\
\text { a table to } \\
\text { record the } \\
\text { average } \\
\text { growth of } \\
\text { sprouted } \\
\text { seeds. }\end{array}$ & $\begin{array}{l}\text { [2] Students } \\
\text { make a table } \\
\text { to write } \\
\text { down the } \\
\text { average } \\
\text { growth of } \\
\text { seed sprouts } \\
\text { from the } \\
\text { results of } \\
5 \text { days and } \\
\text { describe the } \\
\text { project on } \\
\text { a sheet of } \\
\text { paper. }\end{array}$ \\
\hline Monitoring & $\begin{array}{l}\text { [3] The } \\
\text { teacher } \\
\text { accompanies } \\
\text { the students } \\
\text { in completing } \\
\text { the webbing. }\end{array}$ & $\begin{array}{l}\text { [3] Students } \\
\text { determine the } \\
\text { material to } \\
\text { make woven, } \\
\text { namely } \\
\text { coconut } \\
\text { leaves and } \\
\text { banana leaves }\end{array}$ & $\begin{array}{l}\text { [3] The teacher } \\
\text { assists } \\
\text { students in } \\
\text { completing } \\
\text { the product. }\end{array}$ & $\begin{array}{l}\text { [3] Students } \\
\text { determine } \\
\text { materials } \\
\text { and } \\
\text { determine } \\
\text { costs to } \\
\text { design } \\
\text { products. }\end{array}$ \\
\hline
\end{tabular}




\begin{tabular}{|c|c|c|c|c|}
\hline $\begin{array}{l}\text { Assessing } \\
\text { results }\end{array}$ & $\begin{array}{l}\text { [4] The } \\
\text { teacher } \\
\text { accompanies } \\
\text { the students } \\
\text { in making } \\
\text { webbing from } \\
\text { experimental } \\
\text { coconut } \\
\text { and banana } \\
\text { leaves. }\end{array}$ & $\begin{array}{l}\text { [4] Students } \\
\text { conduct } \\
\text { experiments } \\
\text { on making } \\
\text { woven from } \\
\text { coconut and } \\
\text { banana leaves } \\
\text { with the } \\
\text { group }\end{array}$ & $\begin{array}{l}\text { [4] The teacher } \\
\text { accompanies } \\
\text { students in } \\
\text { conducting } \\
\text { experiments. }\end{array}$ & $\begin{array}{l}\text { [4] Students } \\
\text { conduct } \\
\text { experiments } \\
\text { on } \\
\text { optimizing } \\
\text { sprouts. }\end{array}$ \\
\hline $\begin{array}{l}\text { Evaluating } \\
\text { experiences }\end{array}$ & $\begin{array}{l}\text { [5] The } \\
\text { teacher } \\
\text { provides } \\
\text { input and } \\
\text { provides } \\
\text { solutions } \\
\text { to the } \\
\text { difficulties }\end{array}$ & $\begin{array}{l}\text { [5] Students } \\
\text { present } \\
\text { the results } \\
\text { of making } \\
\text { webbing }\end{array}$ & $\begin{array}{l}\text { [5] The teacher } \\
\text { provides } \\
\text { input and } \\
\text { provides } \\
\text { solutions } \\
\text { to the } \\
\text { difficulties } \\
\text { found by } \\
\text { students. }\end{array}$ & $\begin{array}{l}\text { [5] Students } \\
\text { present the } \\
\text { results of the } \\
\text { experiment. }\end{array}$ \\
\hline
\end{tabular}

STEM learning activities with types of energy topics can also be applied at lower and upper levels to construct knowledge of various types of energy, energy conversion, and energy sources in the environment. Table 7 shows the potential of STEM learning procedures with a study of energy.

Table 7. Potential project-based learning procedures with a STEM approach with an energy concept understanding orientation

\begin{tabular}{|c|c|c|c|c|}
\hline \multirow{2}{*}{$\begin{array}{l}\text { Project- } \\
\text { Based } \\
\text { Learning } \\
\text { Procedure }\end{array}$} & \multicolumn{2}{|c|}{$\begin{array}{l}\text { The energy of motion (Class III) } \\
\text { Learning Project: Windmill } \\
\text { (modified from Fuadi, 2015) }\end{array}$} & \multicolumn{2}{|c|}{$\begin{array}{c}\text { Simple electrical circuit (Class IV) } \\
\text { Learning Project: Simple electric } \\
\text { circuit (modified from Fantuzzo \& } \\
\text { Ginsburg-Block, 1998) }\end{array}$} \\
\hline & $\begin{array}{l}\text { Teacher's } \\
\text { Activities }\end{array}$ & $\begin{array}{l}\text { Students' } \\
\text { Activities }\end{array}$ & Teacher's Activities & $\begin{array}{l}\text { Students' } \\
\text { Activities }\end{array}$ \\
\hline $\begin{array}{l}\text { Identifying } \\
\text { the problem }\end{array}$ & $\begin{array}{l}\text { [1] The teacher } \\
\text { asks } \\
\text { students to } \\
\text { understand } \\
\text { the various } \\
\text { motions of } \\
\text { objects }\end{array}$ & $\begin{array}{l}\text { [1] Students } \\
\text { understand } \\
\text { examples } \\
\text { of object } \\
\text { motion }\end{array}$ & $\begin{array}{l}\text { [1] The teacher } \\
\text { shows a video } \\
\text { example of a } \\
\text { home electrical } \\
\text { system }\end{array}$ & $\begin{array}{l}\text { [1] Students } \\
\text { observe } \\
\text { the video } \\
\text { displayed }\end{array}$ \\
\hline
\end{tabular}




\begin{tabular}{|c|c|c|c|c|}
\hline $\begin{array}{l}\text { Drafting } \\
\text { designs and } \\
\text { schedules }\end{array}$ & $\begin{array}{l}\text { [2] Students } \\
\text { are asked } \\
\text { to design } \\
\text { or design } \\
\text { windmill } \\
\text { media from } \\
\text { paper }\end{array}$ & $\begin{array}{l}\text { [2] Students } \\
\text { make } \\
\text { windmill } \\
\text { media }\end{array}$ & $\begin{array}{l}\text { [2] The teacher } \\
\text { asks students to } \\
\text { think critically } \\
\text { to create a } \\
\text { village ecology } \\
\text { by incorporating } \\
\text { simple } \\
\text { electrical circuit } \\
\text { components }\end{array}$ & $\begin{array}{l}\text { [2] Students } \\
\text { conduct } \\
\text { experiments } \\
\text { using organic } \\
\text { grain products } \\
\text { and electrical } \\
\text { circuits for } \\
\text { street lights }\end{array}$ \\
\hline Monitoring & $\begin{array}{l}\text { [3] The teacher } \\
\text { accompanies } \\
\text { students in } \\
\text { completing } \\
\text { the windmill } \\
\text { media }\end{array}$ & $\begin{array}{l}\text { [3] Students } \\
\text { determine } \\
\text { the } \\
\text { materials } \\
\text { to make a } \\
\text { windmill }\end{array}$ & $\begin{array}{l}\text { [3] The teacher } \\
\text { assists students } \\
\text { in completing } \\
\text { the product }\end{array}$ & $\begin{array}{l}\text { [3] Students } \\
\text { determine } \\
\text { materials and } \\
\text { determine } \\
\text { costs to design } \\
\text { products }\end{array}$ \\
\hline $\begin{array}{l}\text { Assessing } \\
\text { results }\end{array}$ & $\begin{array}{l}\text { [4] The teacher } \\
\text { accompanies } \\
\text { students in } \\
\text { conducting } \\
\text { experiments }\end{array}$ & $\begin{array}{l}\text { [4] Students } \\
\text { experiment } \\
\text { with paper } \\
\text { windmills }\end{array}$ & $\begin{array}{l}\text { [4] The teacher } \\
\text { accompanies } \\
\text { students in } \\
\text { conducting } \\
\text { experiments. }\end{array}$ & $\begin{array}{l}\text { [4] Students } \\
\text { experimented } \\
\text { on optimizing } \\
\text { sprouts. }\end{array}$ \\
\hline $\begin{array}{l}\text { Evaluating } \\
\text { experiences }\end{array}$ & $\begin{array}{l}\text { [5] The teacher } \\
\text { provides } \\
\text { input and } \\
\text { provides } \\
\text { solutions } \\
\text { to the } \\
\text { difficulties }\end{array}$ & $\begin{array}{l}\text { [5] Students } \\
\text { present } \\
\text { the results } \\
\text { of the } \\
\text { experiment }\end{array}$ & $\begin{array}{l}\text { [5] The teacher } \\
\text { provides input } \\
\text { and provides } \\
\text { solutions to the } \\
\text { difficulties found } \\
\text { by students. }\end{array}$ & $\begin{array}{l}\text { [5] Students } \\
\text { present the } \\
\text { results of the } \\
\text { experiment. }\end{array}$ \\
\hline
\end{tabular}

The development of STEM education research in Indonesia has begun to be developed at various levels of education, especially the basic education level to support the implementation of the 2013 curriculum. The learning projects that can be produced also vary, which is shown in various potential STEM-based learning procedures by integrating several subjects at grade level. lower and upper elementary school. This potential can be seen in recreational, environmental, and energy types of learning. From existing research, educators are required to be more creative in delivering learning and making students directly involved in the learning process. The STEM approach is one approach that can be used to improve the quality of learning, which initially had many weaknesses in the learning process so that it would become more meaningful. 


\section{CONCLUSIONS}

A systematic review of scientific articles indexed on the Sinta page shows that there are developments in STEM research at the elementary school level in Indonesia every year. The most distribution of articles on STEM education themes was found in journals with the scope of educational studies that were ranked at Sinta 3. A review of 17 articles that matched the criteria for the PRISMA method showed that there were variations in projects that could be analyzed further from the 7 articles. Learning projects cover recreational, environmental, and energy topics. The findings show that research on STEM learning projects tends to be carried out in upper grades in elementary schools. Research to develop STEM education research at the lower and upper levels has a very large potential to be carried out. This is indicated by the variety of potential projects that may be developed with the procedures of the project-based learning model. Further research is needed to see how the potential projects offered through literature review can be implemented and developed through field research. 


\section{REFERENCES}

Abidin, Z., Utomo, A. C., Pratiwi, V., Farokhah, L., Surakarta, U. M., Jakarta, U. B., \& Jakarta, U. M. (2020). Project-Based Learning-Literacy in Improving Students' Mathematical Reasoning Abilities in Elementary Schools. JMIE : Journal of Madrasah Ibtidaiyah Education, 4(1), 43.

Agus, E. (2018). Tematik STEM Education Membuat Es Krim. Youtube Uploaded by Nur Fitriani.

Cahyana, Hamdu, G., Abdul, D., Lidinillah, M., \& Apriliya, S. (2020). Electrical Tandem Roller ( ETR ) Media for 4C Capabilities Based Stem Learning Elementary Schools. International Journal of Elementary Education, 4(2), 171.

Dugger, W.E. (2010). Evolution of STEM in the United States. 6Th Biennial International Conference on Technology Education Research, March, 1-8. http://www. iteea.org/Resources/PressRoom/AustraliaPaper.pdf

Erviana, V. Y. (2019). Pengembangan Ensiklopedia Terintegrasi STEM (Science, Technology, Engineering, Mathematics) Sebagai Pengayaan Bagi Peserta Didik. Jurnal Inovasi Pendidikan Dasar, 5(1), 34.

Fantuzzo, J., \& Ginsburg-Block, M. (1998). STEAM Implementations for Elementary School Students in Tukey. Journal of STEM Arts, Craft, and Constructions, $3(2), 47$.

Faridawati, F., Minarto, E., Wati, I. I., Sutrisno, \& Hakim, L. (2020). Pembelajaran Robotik untuk Mempersiapkan Generasi Muda Menghadapi Revolusi Industri 4.0 dan Society 5.0. Jurnal Pengabdian Kepada Masyarakat: Teknologi Dan Aplikasi, 1(2), 89.

Febriyanti, D., \& Maryani, I. (2020). Pengembangan LKPD Berbasis STEM pada Materi IPA Tema 7 Subtema 1 Kelas V Sekolah Dasar. Fundamental Pendidikan Dasar, 3(2), 165.

Firdaus, A. R., Dani, G., \& Rahayu, S. (2019). Effect of STEM-based Learning on the Cognitive Skills Improvement. Mimbar Sekolah Dasar, 6(2), 201. https:// doi.org/10.17509/mimbar-sd.v6i2.17562

Fuadi, M. S. (2015). Pengembangan Bahan Ajar IPA Materi Penerapan Konsep Energi Gerak Berbasis Pratikum untuk Meningkatkan Pemahaman Konsep Siswa Kelas III SDN Langlang Singosari Malang. Universitas Islam Negeri Maulana Malik Ibrahim Malang. 
Gladden, L. B. (2008). Cause and effect. Journal of Applied Physiology (Bethesda, Md. : 1985), 105(1), 364.

Hariyati, R. T. S. (2010). Mengenal Sistem Review Theory dan Studi Kasus. Jurnal Keperawatan Indonesia, 13, 124.

Hinton. (2020). 1st Grade STEM Lesson. Youtube Poaded by Paul Flores.

Imaduddin, M., Praptaningrum, D. N. W., \& Safitri, D. A. (2021). Students' Attitude toward STEM Project-Based Learning in the Fun Cooking Activity to Learn about the Colloid System. International Journal of Contemporary Educational Research, 8(1), 14-26. https://doi.org/10.33200/ijcer.820898

Kementerian Perindustrian Republik Indonesia. (2018). Making Indonesia 4.0. 1-8. https://kemenperin.go.id/download/18427

Kurniasih, Y., Hamdu, G., Abdul, D., \& Lidinillah, M. (2020). Asesmen Kinerja Berpikir Kritis pada Pembelajaran STEM dengan Media Lightning Tamiya Car. Jurnal Ilmiah Sekolah Dasar, 4(2), 178.

Kurniawan, H. (2018). Implementasi Pembelajaran IPA Berbasis STEM untuk Meningkatkan Kemampuan Komunikasi Siswa.

Lely, P., Prabawati, S., Ngurah, G., \& Agustika, S. (2020). Project-Based Learning Based On Stem ( Science, Technology, Engineering, And Mathematics ) Enhancing Students Science Knowledge Competence. Jurnal Ilmiah Sekolah Dasar, 4(4), 624.

Lidinillah, D. A. M., Mulyana, E. H., Karlimah, K., \& Hamdu, G. (2019). Integration of STEM learning into the elementary curriculum in Indonesia: An analysis and exploration Integration of STEM learning into the elementary curriculum in Indonesia: An analysis and exploration. IOP, 2. https://doi. org/10.1088/1742-6596/1318/1/012053

Lou, S.-J., Chuang, S.-Y., Meng, H., Yeh, R. C., \& Chang, T. K.-H. T. C.-C. (2010). A Study of Project-Based STEM Learning for Senior High School Students in Taiwan. In American Society for Engineering Education (pp. 1-9).

Maula, N. R., \& Fatmawati, L. (2020). Pengembangan Media Pembelajaran Kayaku ( Kayanya Alam Negeriku ) Berbasis STEM Kelas IV Sekolah Dasar. Jurnal Ilmiah Sekolah Dasar, 4(1), 100. 
Ministry of Research and Technology /National Agency for Research and Innovation. (2017). AboutSinta (Science and Technology Index). Https://Sinta.Ristekbrin. Go.Id/. https://sinta.ristekbrin.go.id/about

Narti. (2015). Kurikulum 2013 SD Kelas 2 Tema 2. Youtube, Uploaded by Henry.

Nurwulan, N. R. (2020). Pengenalan Metode Pembelajaran STEAM Kepada Para Siswa Tingkat Sekolah Dasar Kelas 1 Sampai 3. Madaniya, 1(3), 142.

Oktapiani, N., \& Hamdu, G. (2020). Desain pembelajaran stem berdasarkan kemampuan 4c di sekolah dasar. Jurnal Ilmiah Pendidikan Dasar, VII(2), 108.

Oktaviani, V. A., Lyesmaya, D., \& Maula, L. H. (2020). Meningkatkan Pemahaman Konsep Matematika Menggunakan Pendekatan STEAM (Science, Technology, Engineering, Arts, dan Mathematics) Berbasis Daring. (JKPD) Jurnal Kajian Pendidikan Dasar, 5(2), 142.

Priyani, N. E., \& Nawawi, N. (2020). Pembelajaran Ipa Berbasis Ethno-Stem Berbantu Mikroskop Digital Untuk Meningkatkan Keterampilan Proses Sains Di Sekolah Perbatasan. WASIS : Jurnal Ilmiah Pendidikan, 1(2), 99-104. https:// doi.org/10.24176/wasis.v1i2.5435

Rahmat, A. A., Hamdu, G., Nur'aeni, E., Muiz, D. A., \& Lidinillah. (2020). Pengembangan Soal Tes Tertulis Berbasis Stem Dengan Pemodelan Rasch di Sekolah Dasar. Jurnal DIDIKA : Wahana Ilmiah Pendidikan Dasar, VI(1), 27.

Rahmawati, B. A. (2020). Implementasi Pembelajaran Berbasis STEAM dalam Menumbuhkan Keterampilan Berpikir Kritis di SD My Litle Island Malang. Universitas Islam Negeri Maulana Malik Ibrahim Malang.

Sabillah, D. S. (2020). Pengembangan Instrumen Penilaian Sikap Pada Pembelajaran STEM dengan Media Perahu Bertenaga Uap di Kelas V Sekolah Dasar. Fundamental Pendidikan Dasar, 3(2), 147.

Sariah. (2016). Panduan Pelaksanaan Sains, Teknologi, Kejuruteraan dan Matematik (STEM) dalam Pengajaran dan Pembelajaran. Putrajaya.

Seage, S. J., \& Türegün, M. (2020). The effects ofblended learning on STEM achievement of elementary school students. International Journal of Research in Education and Science, 6(1), 133-140. https://doi.org/10.46328/ijres.v6i1.728

Septine, N. V., Wijayanti, O., \& Badarudin. (2019). Peningkatan sikap ilmiah dan prestasi belajar menggunakan model Science, Technology, Engineering , and Mathematics di kelas V MIM kramat. Premiere Educandum: Jurnal 
Pendidikan Dasar Dan Pembelajaran, 9(2), 96. https://doi.org/10.25273/ pe.v9i2.4470

Siswanto. (2010). Systematic Review Sebagai Metode Penelitian untuk Metasintesis Hasil-hasil Penelitian (Sebuah Pengantar). Buletin Penelitian Sistem Kesehatan, 13(4), 328.

Slavit, D., Nelson, T. H., \& Lesseig, K. (2016). The teachers' role in developing, opening, and nurturing an inclusive STEM-focused school. International Journal of STEM Education, 3(1). https://doi.org/10.1186/s40594-016-0040-5

Soldiana. (2018). Pembelajaran Kooperatif Student STEAM Achievement dalam Upaya Meningkatkan Hasil Belajar PKN Siswa Kelas V SD Negeri 168060 Kota Tebing Tinggi. ESJ (Elementary School Journal)), 8(4), 308.

Sukmana, R. W. (2017). Pendekatan Science, Technology, Engineering and Mathematics (STEM) Sebagai Alternatif dalam Mengembangkan Minat Belajar Peserta Didik Sekolah Dasar. Pendas: Jurnal Ilmiah Pendidikan Dasar, II, 195.

Twiningsih, A., \& Sayekti, T. (2020). Peningkatan Keterampilan Berhitung Siswa Melalui Media Kotak Ajaib Berbasis STEM pada Materi Konsep Penjumlahan. JPD: Jurnal Pendidikan Dasar, 11(1), 10.

Ultay, N., Zıvalı, A., Yılmaz, H., Bak, H. K., Yılmaz, K., Topatan, M., \& Kara, P. G. (2020). STEM-Focused Activities to Support Student Learning in Primary School Science. Journal of Science Learning, 3(3), 156-164. https://doi. org/10.17509/jsl.v3i3.23705

Wahono, R. S. (2015). A Systematic Literature Review of Software Defect Prediction: Research Trends, Datasets, Methods and Frameworks. Journal of Software Engineering, 1(1), 1-16. https://doi.org/10.3923/jse.2007.1.12

Wahyu, R. (2018). Implementasi Model Project Based Learning ( PJBL ) Ditinjau dari Penerapan Implementasi Model Project Based Learning ( PJBL ) Ditinjau dari Penerapan Kurikulum 2013. Teknoscienza, 1(1), 57.

Wijokongko. (2009). Pembelajaran STEM di Queensland Australia STEM Learning in Queensland Australia. JURNAL IDEGURU, 4(1), 101.

Winarni, J., Zubaidah, S., \& H, S. K. (2016). STEM: apa, mengapa, dan bagaimana. In Prosiding Seminar Nasional Pendidikan IPA Pascasarjana UM (Vol. 1, pp. 976-984). 
Yuanita, \& Kurnia, F. (2019). Pengembangan Bahan Ajar Berbasis STEM (Science, Tchnology, Engineering, and Mathematics) Materi Kelistrikan untuk Sekolah Dasar. Profesi Pendidikan Dasar, 6(2), 199. https://doi.org/10.23917/ppd. v1i2.9046 